\title{
PENERAPAN SAINTIFIK PADA PEMBELAJARAN PENDIDIKAN AGAMA ISLAM (SD Islam Bina Insani Muslim Bekasi)
}

\author{
Mia Fitrah Elkarimah \\ Program Studi Bahasa Inggris, Universitas Indraprasa PGRI Jakarta \\ Email: el.karimah@gmail.com
}

\begin{abstract}
Abstrak
Penelitian ini bertujuan untuk mendeskripsikan penerapan kurikulum k13 khususnya langkah-langkah saintifik pada mata pembelajaran PAI di SD Islam Bina Insani Muslim Jatimulya Kec. Tambun selatan Kab bekasi. Instrumen penelitian ini menggunakan pedoman observasi, wawancara dan dokumentasi, untuk menganalisis data penelitian ini menggunakan teknik deskriptif kualitatif. Hasil penelitian satu bulan menunjukkan bahwa penerapan langkah-langkah saintifik sudah dilaksanakan secara keseluruhan. Namun pada pelaksanaannya belum semua sesuai dengan Peraturan Menteri Pendidikan dan Kebudayaan RI yang meliputi 5 langkah yaitu: mengamati, menanya, mencoba, menalar atau asosiasi, dan mengkomunikasikan. Ketidakoptimal langkah-langkah saitifik pada pembelajraan PAI bisa terlihat pada pelaksanaannya yang tidak berurutan langah-langkahnya. Pada kegiatan mengamati pada aspek aqidah menjadi kendala yang dominan. Karena Aspek aqidah memuat konsep pengetahuan yang berhubungan dengan kepercayaan dan karakternya adalah abstrak. Kegiatan berdiskusi ini cenderung gaduh dan tidak terfokus. Sedangkan kegiatan meniru hanya teraplikasikan pada aspek fiqih saja, seperti materi tata cara bersuci, sedangkan pada aspek al-Qur'an hadits, siswa merasa kesulitan mengasosiasikan isi kandungan alQur'an dengan fenomena kehidupan sehari-hari, apalagi bagi siswa yang baru saja dapat membaca al-Qur'an. kegiatan mengomunikasikan ide, masih tidak tertata dan cenderung diam.
\end{abstract}

Kata Kunci : Kurikulum 2013, Langkah-langkah saintifi, Pendidikan Agama Islam

\begin{abstract}
This research aims to describe the application of curriculum k13, especially scientific steps on the PAI (Islamic Education) subject in Islamic Elementary School Bina Insani Muslim Jatimulya in South Tambun subdisstrict, Bekasi Regency. The research instruments consist of observation, interview and documentation. The data of the research are analyzed employing a qualitative descriptive technique. The result of the one-month research shows that the scientific steps have been implemented as a whole. However, its implementation is not in accordance with the regulations of Minister of Education and Culture of Republic of Indonesia, consisting of 5 steps: observing, asking, trying, reasoning or associating and communicating. The inadequacy of the scientific steps in PAI learning can be seen in its non-sequential implementation. In the observing step, the aspect of aqidah (faith) is a dominant obstacle because it contains the concept of knowledge that is related to a belief and its abstract character. The discussions in this step tend to be rowdy and not focused. Besides, the imitating activity is only applied to aspects of fiqih (jurisprudence), such as the material of cleaning procedure. In the associating step, especially on the aspects of Al-Qur'an and hadith, students find it difficult to associate the contents of Al-Qur'an with the phenomena in their daily life, especially for students who have just learned to read Al-Qur'an. The last one is communicating ideas has not organized yet and tends to be quiet.
\end{abstract}

Keywords: curriculum 2013, scientific steps, Islamic Education

\section{PENDAHULUAN}

Langkah-langkah saintifik sangat dikenal dengan munculnya kurikulum 2013. Langkah-langkah saintifik memberikan ciri khas terhadap lahirnya kurikulum yang berbasis active learning ini. sehingga tak heran setiap kegiatan baik itu pelatihan dan workshop berorientasi pada kurikulum baru, khususnya langkah-langkah saintifik yang menjadi ciri khas kurikulum 2013. 
Langkah-langkah Scientific sebagaimana disampaikan dalan Permendikbud Nomor 103 Tahun 2014 meliputi lima langkah yaitu mengamati, menanya, mencoba, menalar, dan mengkomunikasikan.

Sedangkan pendekatan dapat diartikan sebagai sudut pandang bagi pendidik baik guru dan dosen atau instruktur terhadap proses pembelajaran. Pendekatan akan menjadi kompas untuk menetapkan arah umum yang jelas dan terperinci tentang pembelajaran. pendekatan juga bisa diartikan dengan serangkaian asumsi yang terkait langsung dengan hakekat pembelajaran [1].

Penggunaan langkah-langkah saintifik harus diamplikasikan pada semua mata pelajaran, tak terkecuali pelajaran Pendidikan Agama Islam (PAI), Pendidikan Agama Islam adalah pendidikan yang tidak hanya memberikan pengetahuan dan keterampilan tetapi juga membentuk sikap dan kepribadian peserta didik menjadi seorang muslim yang ideal. Untuk PAI mencakup empat aspek yaitu qur'an-hadis, akidah-akhlak, fikih, dan sejarah kebudayaan islam. Masing-masing aspek saling kait mengait, saling melengkapi. Qur'an hadis merupakan sumber utama ajaran Islam, fikih merupakan sebuah hukum atau aturan yang disyariatkan, sedangkan sejarah kebudayaan Islam hanya baru sekedar sejarah Nabi-Nabi untuk diambil teladan dalam kegiatan pembelajaran PAI.

Menurut penjelasan Kemendikbud melalui Tim Pusat Kurikulum dan Perbukuan tahun 2013 yang dimuat pada tulisannya Fahrul Usmi menjelaskan bahwa pembelajarn dengan menggunakan langkah-langkah saintifik mempunyai ciri khas sebagai berikut : Proses pembelajaran harus bersifat yang logis, artinya berbasis fakta, data yang dapat dijelaskan bukan sebatas kira-kira atau dongeng semata.
Explanasi guru yang dibungkus dalam interaksi edukatif guru-siswa terbebas dari prasangka yang serta-merta, sehingga menginspirasi siswa berpikir secara kritis [2].

Penerapan langkah-langkah saintifik pada mapel PAI harus selalu dibangun atas dasar prinsip metode ilmiah sebagaimana diterangkan di atas. Seperti berbasis pada fakta, berpikir kritis, berpikir hipotetik, objektif. Tetapi hal yang harus dingat dan disadari bahwa ternyata ada materi yang sangat memungkinkan jika pendekatan ilmiah tidak diaplikasikan secara prosedural. Bukan berarti tidak menerapkan nilai-nilai ilmiah, tetapi ada hal yang harus diketahui bahwa dalam pengajaran PAI ada aspek yang terkadang tidak bisa untuk masuk langkah saintifik, maksudnya tidak bisa diraba secara empiris, seperti tema aqidah dan tauhid yang butuh pada sebuah keyakinan.

Metode pengajaran dan pendekatan dalam pembelajaran PAI masih berkutat pada kisaran kognitif, padahal pembelajaran PAI harusnya lebih fokus pada pengembangan potensi afektif dan psikomotorik siswa secara maksimal, jauh dari pengayaan spiritual, etik dan moral sehingga peserta didik secara verbal dapat memahami ajaran Islam akan tetapi kurang menghayati maknanya.

Model pembelajaran PAI di sekolah masih terpaku pada model konvensional yang bersifat monolog dan doktrinatif. Lebih jauh lagi menurut Nurlena Rifa'i bahwa model-model pembelajaran PAI tidak mendidik dan tidak menjadikan siswa/siswi aktif, kreatif dan inovatif sesuai dengan harapan [3].

Oleh karena itu penelitian tentang bagaimana penerapan langkah-langkah saintifik melatar belakangi penelitian ini, dan objek penelitiannya adalah SD Islam 
Bina Insani Muslim kelas I dan 2. Peneliti merasa tertarik untuk memilih SD Islam Bina Insani Muslim karena pendidikan karakter sudah diterapkan, mengingat kurikulum 2013 adalah pendidikan yang terfokus pada pendidikan karakter. Disamping itu PAI diajarkan secara mendetail dan langsung dipraktekkan sehingga siswa bisa memahami dan mempraktekkannya secara langsung. Dalam melakukan pembelajaran setiap hari tentunya setiap sekolah mempunyai konsep dan cara masing-masing, namun perlu adanya kurikulum yang mewadahi semua tujuan tersebut sebagai acuan agar kegiatan pembelajaran menjadi satu arah dan linier.

\section{METODE}

Penelitian ini menggunakan metode deskriptif, pendekatan kualitatif. Subjek penelitian ini adalah guru mapel PAI dan peserta didik kls 1 dan 2 SD Islam Bina Insani Muslim. Instrumen penelitian ini menggunakan pedoman observasi, pedoman wawancara dan dokumentasi. Teknik yang digunakan untuk menganalisis data menggunakan teknik deskriptif kualitatif

Penelitian ini bertujuan untuk mendeskripsikan bagaimana penerapan langkah-langkah saintifik pada pelajaran pendidikan agama islam di Sekolah Dasar Islam Bina Insani Muslim serta mendeskripsikan apa yang menjadi penghambat dalam menerapkan langkahlangkah saintifik pada pelajaran pendidikan agama islam. manfaat dan hasil penelitian ini diharapkan dapat menambah pengetahuan dan wawasan keilmuan. Penelitian ini menggunakan pendekatan kualitatif yaitu penelitian yang mengedepankan pengumpulan data atau realisasi personal dengan berlandaskan pada penyajian data yang diungkapkan guru PAI dan kondisi peserta didik.

\section{HASIL DAN PEMBAHASAN}

\section{Langkah-langkah saintifik Kurikulum} 2013

Beberapa hal yang menjadi pembeda kurikulum 2013 dengan kurikulum sebelumnya adalah kurikulum 2013 semua mata pelajaran dirancang saling terkait satu dengan lainnya yang diikat oleh kompetensi inti di tiap kelas. Kedua, semua mata pelajaran diajarkan dengan langkah-langkah saintifik .

Pendekatan adalah konsep dasar yang mewadahi dan melatari pemikiran tentang bagaimana metode pembelajaran diterapkan berdasarkan teori tertentu [4]. Scientific berasal bahasa Inggris yang berarti ilmiah, maksudnya semua berdasarkan ilmu pengetahuan. Sedangkan Scientific tidak lepas dari pendekatan. Dengan demikian, maka pendekatan ilmiah (Scientific Approach) dalam pembelajaran yang dimaksud disini adalah bagaimana metode pembelajaran diterapkan berdasarkan teori tertentu ilmiah [5].

Pembelajaran menggunakan langkahlangkah saintifik yaitu suatu proses pembelajaran agar siswa-siswi aktif dalam tahapan-tahapan mengamati, merumuskan masalah, mengajukan atau merumuskan hipotesis, mengumpulkan data dengan berbagai teknik, menarik kesimpulan dan mengkomunikasikan [6].

Langkah-langkah saintifik tidak hanya fokus bagaimana mengembangkan kompetensi peserta didik dalam melakukan observasi, namun bagaimana mengembangkan pengetahuan dan ketrampilan berpikir sehingga dapat mendukung aktifitas kreatif dalam mengamati, menanya, mengeksplorasi, mengasosiasi dan mengkomunikasikan.

Sedangkan langkah-langkah ini harus pada materi pembelajaran yang harus berbasis pada fakta yang dapat dijelaskan dengan 
logika atau penalaran tertentu. Sehingga hasil dari pembelajaran berbasis langkahlangkah saintifik ini lebih efektif daripada pembelajaran tradisional. Menurut Daryanto penelitian membuktikan bahwa pada pembelajaran tradisional, retensi informasi dari guru sebesar 10 persen setelah 15 menit dan perolehan pemahaman kontekstual sebesar 25 persen. Pada pembelajaran berbasis pendekatan ilmiah, retensi informasi dari guru sebesar lebih dari 90 persen setelah dua hari dan perolehan pemahman kontekstual sebesar 50-70 persen Daryanto [7].

Adapun tahapan-tahapan langkah-langkah saintifik ini :

\section{a. Mengamati}

Kegiatan pengamatan dalam proses pembelajaran meniscayakan keterlibatan peserta didik secara langsung. Dalam kaitan ini, guru harus memahami bentuk keterlibatan peserta didik secara langsung. Kita bisa mengambil contoh yang dilakukan oleh nabi Ibrahim as ketika menemukan Tuhannya. Bagaimana Nabi Ibrahim melihat bintang-bintang yang indah, lalu rembulan yang menawan, kemudian matahari yang menakjubkan, kemudian menyimpulkan ada sesuatu yang maha besar dibalik keindahan ciptaanya

"Sesungguhnya aku menghadapkan diriku kepada Rabb yang menciptakan langit dan bumi, dengan cenderung kepada agama yang benar, dan aku bukanlah termasuk orang-orang yang mempersekutukan Tuhan" (QS 6:79). Proses pembelajaran yang dilakukan nabi Ibrahim sejalan dengan proses dalam pembelajaran yang diawali denan kegiatan mengamati

\section{b. Menanya}

Proses pembelajaran yang berbasis pertanyaan ini dapat dikembangkan dalam beberapa bentuk metode pembelajaran, seperti teknik tanya jawab dan metode student question. Dalam proses penyampaikan informasi tanya jawab bisa berlansung, teknisnya bisa dari siswa ke guru, dari siswa ke siswa, ataupun dari guru ke siswa. Teknik ini juga memberikan manfaat untuk menstimulus siswa untuk lebih memperhatikan pada informasi yang sedangdiberikan. Selain memberikan stimulus teknik tanya jawab juga dapat menjadi icebreaking yang dapat menumbuhkan konsentrasi dan focus siswa terhadap proses pembelajaran yang sedang berlangsung.

Student question merupakan pembelajaran yang disesuaikan dengan kebutuhan, disini pertanyaan sebagai sumber belajar, biasanya terbagi beberapa kelompok atau individu.

\section{c. Mengeksperimen / Mencoba}

Kegiatan ini merupakan tindak lanjut dari proses menanya. Untuk memperoleh hasil belajar, peserta didik harus mencari tahu apa yang sedang dipelajari atau melakukan percobaan, terutama untuk materi atau subtansi yang sesuai.

\section{d. Mengasosiasi / Menalar}

Proses ini mengajak siswa-siswi untuk berfikir yang logis dan sistematis. Kegiatan "mengasosiasi/ menalar" dalam kegiatan pembelajaran adalah memproses informasi yang sudah dikumpulkan biasanya dari hasil kegiatan, lalu mencari solusi dari berbagai sumber. Dalam pembelajaran guru berperan memotivasi dan memberikan fasilitas untuk peserta didik agar mereka menggunakan daya fikir mereka. Dalam penerapannya guru memberikan sajian metode biasanya menggunakan konsep Mind Mapping; metode dengan cara mencatat lalu memetakan pikiran-pikiran.

\section{e. Mengkomunikasi}

Proses mengkomunikasikan bisa dengan kegiatan menuliskan atau menceritakan kembali apa yang ditemukan dalam 
kegiatan mencari informasi. Hasil tersebut disampaikan di kelas. Adapun kompetensi yang yang diharapkan dalam kegiatan ini adalah mengembangkan sikap jujur, dan dapat mengungkapkan pendapat dengan singkat dan jelas, dan mampu mengembangkan bahasa siswa-siswi.

Adapun alternatif pendekatan yang dapat digunakan untuk melaksanakan pembelajaran dengan basis saintifik antara lain dengan Project Based Learning/Product Based Learning, Problem Based Learning/Problem Solving dan Discovery Learning/Inquiry/CTL. Project based learning adalah pembelajaran dengan menggunakan proyek atau produk sebagai pendekatan pembelajaran untuk mencapai kompetensi sikap, pengetahuan, dan keterampilan. Problem Based Learning (pembelajaran berbasis masalah/PBM) adalah pembelajaran yang menggunakan masalah nyata (autentik) dan bersifat terbuka sebagai konteks bagi peserta didik untuk mengembangkan keterampilan menyelesaikan masalah dan berpikir kritis serta sekaligus membangun pengetahuan baru. Pembelajaran Kontekstual (Contextual Teaching \& Learning), metode inkuiri merupakan metode yang mempersiapkan peserta didik pada situasi untuk melakukan eksperimen sendiri secara luas [8].

\section{Pendidikan Agama Islam Dalam Kurikulum 2013}

Secara umum ada 4 elemen perubahan yang dikembangkan pada kurikulum 2013, yaitu Standar Kompetensi Lulusan (SKL), Standar Isi (SI), Standar Proses dan Standar Penilaian. Standar disebut sebagai patokan atau bisa juga dikatakan sebagai kriteria minimal. Sebuah standar seringkali titik acuannya pencapaian hanya pencapaian minimal, begitu juga dengan standar isi, standar isi menurut UUSP no.20 tahun 2003 merupakan criteria minimal, batas, patokan, syarat yang harus dicapai dalam peningkatan mutu [9].

Beberapa elemen perubahan kurikulum 2013 dari kurikulum sebelumnya pada PP No. 32 tahun 2013 sebagai pengganti PP No. 19 tahun 2003 tentang Standar Nasional Pendidikan, adalah aspek materi.

Aspek materi dari berbagai mata pelajaran apapun memiliki kompetensi inti yang sama yakni menghasilkan peserta didik yang memiliki kompetensi sikap spiritual, sosial, serta memiliki kompetensi pengetahuan dan keterampilan. Keempatnya harus dikuasai oleh siswa karena jika salah satunya tidak ada maka siswa didik dinyatakan kurang dari kompetensi minimal. Hal ini menjadi satu pembeda dari kurikulum sebelumnya yang menjadikan pengetahuan sebagai tujuan utama.

Pendekatan PAI pada Kurikulum 2013 yang mengusung konsep integrasi (terpadu) yang meliputi: (1) Keimanan yang memberikan kesempatan kepada peserta didik untuk mengembangkan pemahaman adanya Tuhan sebagai sumber nilai universal. (2) Pengamalan untuk memberikan peluang kepada siswa - siswi untuk dapat merasakan dan mempraktikkan nilai universal ajaran Islam dalam menghadapi tugas dan perannya di kehidupan. (3) Pembiasaan untuk memberi kesempatan kepada peserta didik untuk menjadikan nilai-nilai Islam sebagai sikap dan perilaku sehari-hari. (4) Rasional, usaha ini untuk memberikan porsi yang lebih besar kepada akal (rasio)untuk memahami dan membedakan berbagai sistem nilai dalamkehidupan.

Emosional, upaya ini untuk menggugah perasaanpeserta didik dalam menghayati sikap dan perilaku yang sesuai dengannilai-nilai Islam dan budaya bangsa. (6) Fungsional, hal ini menyajikanbentuk semua aspek materi yang memberikan 
kemanfaatan bagikehidupan peserta didik. (7) Keteladanan, yang berarti menjadikansosok guru agama dan orang tua sebagai figur manusia yang berpribadimuslim sehingga dapat dijadikan uswah hasanah. (8) Keterpaduan materi. Keterpaduan yang dimaksudkan adalah pengembangan materi dalam PAI agar ada korelasi antara Al-Qur'an Hadits, Akhlak, ke-imanan dan fiqih-ibadah sehingga akan menghasilkan manusia muslim yang berkepribadian utuh [10].

Pengembangan nilai-nilai dan sikap di dalam materi PAI dilakukandengan cara mengintegrasikan pada semua aspek pembelajaran mulaidari perencanaan sampai evaluasi. Pertama, dimulai dari perencanaan,proses pengintegrasian berawal dari pengintegrasian melalui SKL danKI, melalui KD, Silabus, dan RPP mata pelajaran Pendidikan Agama Islam dan Budi Pekerti. Kedua, pengintegrasian dalam pelaksanaan proses pembelajaran mata pembelajaran PAIdan Budi Pekerti. Ketiga,pengintegrasian dalam proses penilaian mata pembelajaran PAIdan budi Pekerti.Dari penjelasan tentang kurikulum 2013 serta pembelajaran PAI dan Budi Pekerti di atas, dapat dicari arah pengembangan PendidikanAgama Islam di Kurikulum 2013. Dari sisi waktu pembelajaran, pemerintah telah menjawab keluhan guru PAI yang kekurangan jam pelajaran karena padatnya materi PAI.

Perubahan ini menjawab harapan semua pihak yang berarti pula telah mengubah arah pembelajaran Agama Islam yang semula hanya menitikberatkan pada penguasaan teori belaka. PAI saat ini lebih mendorong semua peserta didik agar memiliki skill dan akhlakulkarimah, terlihat dari penambahan "Budi Pekerti" setelah kata PAI.Walaupun sebenarnya tanpa ditambah kata Budi Pekerti pun, PAIsudah mengajarkan dan menjelaskan tentang sikap dan budi pekertiyang baik (akhlak karimah).

\section{Penerapan Pendekatan Saitifik Mapel PAI di SD Islam Bina Insani Muslim}

Pelaksanaan pembelajaran PAI di SD Islam Bina Insani Muslim, mengacu pada tujuan pendidikan umum sebagaimana tercantum dalam Undang -undang Sistem pendidikan Nasional No.20 Tahun 2003, yakni bertujuan untuk berkembangnya potensi peserta didik agar menjadi manusia yang beriman dan bertakwa kepada Tuhan Yang Maha Esa, berahklak mulia, sehat, berilmu, cakap, kreatif, mandiri, dan menjadi warga negara yang demokratis serta bertanggung jawab [11].

Berdasarkan observasi dan wawancara guru mapel PAI bahwa penerapan langkah-langkah saintifik pada pembelajaran PAI di SD Islam Bina Insani Muslim Jatimulya Bekasi secara keseluruhan guru sudah berpegang pada kaidah-kaidah langkah-langkah saintifik , prinsipprinsip langkah-langkah saintifik, namun ada beberapa hal yang masih kurang. Kekurangan tersebut bisa terlihat dari penerapan langkah-langkahnya yang kadang guru tidak runut dalam menggunakanya. Penerapan langkahlangkah saintifik dari proses mengamati terlihat berhasil, siperti siswa fokus melihat gambar tentang peristiwa atau kejadian yang terdapat di buku atau mendengar atau menyimak perkataan guru, seperti saat pembelajaran tentang mengenal kitab-kitab Allah guru memerintahkan siswa untuk memperhatikan atau menyimak bacaan dari guru.

Ketika pada proses selanjutnya yaitu menanya; Guru terlihat mempersilahkan dan membimbing siswa untuk bertanya tentang sesuatu yang telah diamati. Namun demikian siswa kerap mengalami kesulitan untuk bertanya. Sehingga apabila siswa 
tidak mengemukakan pertanyaan, guru yang memberikan pertanyaan kepada siswa untuk merangsang rasa ingin tahu siswa.

Ketiga; proses mengumpulkan informasi atau eksperimen pada langkah-langkah saintifik dilakukan dengan cara mengumpulkan informasi dari sumber buku seperti pada pembelajaran mengenal nama Allah, pembelajaran hormat dan patuh kepada orang tua dan guru, pembelajaran menulis dan memahami makna surat an-Nas, dan pembelajaran sejarah-sejarah Nabi dalam memberikan teladan. Selain itu proses mengumpulkan informasi juga dilakukan dari sumber kejadian atau fenomena yang terjadi dilingkungan sekitar seperti yang dilakukan pada pembelajaran kitab Allah membawa ajaran terpuji dan pembelajaran mengenal kitab-kitab Allah.

Keempat; proses mengasosiasi atau mengolah informasi, guru terlihat menggabungkan informasi yang telah setiap siswa-siswi cari baik secara individu maupun kelompok. Kelima; proses mengkomunikasikan dilakukan setelah siswa selesai berdiskusi atau setelah guru merasa cukup untuk berdiskusi. Kegiatan ini dilakukan dengan perwakilan dari setiap kelompok maju membacakan hasil diskusi kelompoknya dihadapan kelompok lain. Setelah itu guru mengulang hasil diskusi kelompok untuk meluruskan jawaban yang kurang tepat dan untuk menguatkan pemahaman siswa terhadap materi yang telah dipelajari.

Dalam langkah langkah-langkah saintifik pertama yakni kegiatan mengamati. Dalam mengamati, siswa harus disuguhi materi yang berbasis fakta (bisa diindera secara empiris) atau fenomena yang dapat dijelaskan dengan logika atau penalaran tertentu. Bukan hanya sebatas kira-kira, khayalan, legenda, atau dongeng semata. Mengingat objek yang diamati melibatkan peran panca indera, maka objek tersebut harus berupa objekfisik-material. Persoalan yang timbul kemudian tidak semua objek kajian PAI fisik-material, tetapi objek yang metafisik, bahkan eskatologis, seperti hal-hal yang ghaib (malaikat, jin, setan, alam kubur,akhirat, surga atau neraka)

Guru PAI di SD Islam Bina Insani Muslim belum menyadari sepenuhnya bahwa ada cara yang dapat digunakan untuk mengajarkan objek PAI yang bersifat metafisik-eskatologis. Dengan demikian, tidak muncul resistensi yang berlebihan di kalangan guru PAI terhadap langkahlangkah saintifik. Oleh karena itu, perlu dilakukan kajian untuk menguraikan problematika penerapan langkah-langkah saintifik pada mata pelajaran PAI.

Kelas 1 di SD Islam Bina Insani Muslim merupakan siswa yang paling tidak kondusif bila kegiatan mengamati ini dilaksanakan. Kegiatan mengamati ini berisi kegiatan siswa membaca, mendengar, menyimak, melihat, menonton tayangan video dilakukan dengan atau tanpa alat, tidak bisa berjalan dengan maksimal. Siswa SD/MI Contoh, saat guru memutarkan video tentang ciptaan Allah dialam semesta, mereka lebih asyik dengan aktivitasnya sendiri. Pada tingkat kelas yang lebih tinggi, misalnya kelas 2, kegiatan mengamati berjalan relative lebih kondusif. Siswa mau memperhatikan perintah guru agar melakukan kegiatan pengamatan. Namun, tanpa terpikirkan sebelumnya saat pembelajaran materi aqidah (meyakini keberadaan Allah, Nabinabi dan malaikat), guru kebingungan mengaplikasikan langkah ini, sebab malaikat merupakan materi yang abstrak.

Kegiatan mengamati pada aspek lain seperti al-Qur'an hadits juga tidak bisa berlangsung dengan maksimal. Misalnya, pada kelas 2 juga masih banyak siswa yang 
hanya mampu membaca dan menulis latin, sedangkan huruf hijaiyah mereka baru mengenal. Jadi, ketika guru mengintruksikan siswa untukmengaji atau membaca al-Qur'an dan hadits, sebagian siswa hanya terpaku diam membisu.

Sedangkan pada aspek aqidah menjadi kendala yang dominan. Karakteristik aspek aqidah berbeda dengan aspek yang lain seperti sejarah kebudayaan Islam, alQur'an hadits dan fiqih. Aspek aqidah memuat konsep pengetahuan yang berhubungan dengan kepercayaan dan karakternya adalah abstrak (tidak bisa diindera). Karakter ini bertolak belakang dengan muatan kegiatan mengamati yang lebih didominasi domain panca indera. Tentu saja sulit untuk mengaplikasikan kegiatan mengamati pada aspek aqidah.Dalam hal materi yang ada di buku pai k13 kelas satu sudah diajarkan menulis bahasa arab dan huruf hijaiyyah, peserta didik dikelas satu masih kesulitan memahami hal-hal yang berkaitan dengan bahasa arab atau huruf hijayyah

Dalam kegiatan mengumpulkan informasi, serangkaian kegiatan mengumpulkan informasi hanya kegiatan berdiskusi dan meniru gerak yang dapat berjalan dengan baik di sekolah. Kegiatan berdiskusi ini teraplikasikan pada semua aspek PAI, namun siswa cenderung gaduh dan tidak terfokus. Sedangkan kegiatan meniru gerak teraplikasikan pada aspek fiqih, seperti materi tata cara bersuci dan sholat.

Dalam kegiatan mengasosiasi, bagi siswa kelas 1 dan 2 merupakan kegiatan tersulit karena siswa hanya memiliki bekal pengetahuan faktual. Sedangkan dalam mengasosiasi perlu tahap berpikir lebih dari menganalisis. Artinya, dengan bekal pengetahuan faktual saja masih terlalu dini siswa melakukan kegiatan asosiasi. Contoh, pada aspek al-Qur'an hadits, siswa merasa kesulitan mengasosiasikan isi kandungan al-Qur'an dengan fenomena kehidupan sehari-hari.Apalagi bagi siswa yang baru saja dapat membaca al-Qur'an.

Sementara itu, pada kegiatan mengomunikasikan ide, kebanyakan siswa melaporkan hasil pengalaman belajar mereka melalui presentasi. Dan peneliti menyadari bahwa kebanyakan siswa $\mathrm{SD} / \mathrm{MI}$ melakukan presentasi menggunakan tutur bahasa yang lugu, bahkan masih tidak tertata, dengan sikap yang tertutup dan menunjukkan rasa tidak percaya diri.

\section{SIMPULAN}

Kemampuan guru PAI di SD Islam Bina Insani Muslim dalam penerapan langkahlangkah saintifik sudah baik namun belum optimal terutama langkah-langkah langkah-langkah saintifik yang identik dengan ciri khas kurikulum 2013, langkahlangkah langkah-langkah saintifik yang kurang optimal seperti kegiatan mengamati, kegiatan mengumpulkan informasi, kegiatan berdiskusi mengasosiasi dan kegiatan mengomunikasikan

Dalam langkah-langkah langkah-langkah saintifik hanya kegiatan mengumpulkan informasi yang cukup optimal seperti kegiatan meniru gerak teraplikasikan pada aspek fiqih, seperti materi tata cara bersuci dan sholat dan yang paling tersulit langkah langkah-langkah saintifik adalah dalam kegiatan mengasosiasi. Sementara itu, pada kegiatan mengomunikasikan ide, guru PAI kurang menerapkan partisipasi aktif siswasiswi.

\section{DAFTAR PUSTAKA}

[1] Muhammad Yuami. Prinsip-prinsip Desain Pembelajaran. Jakarta; Kencana Prenada Media Group, 2013.

[2] Ahmad Salim. "Langkah-langkah saintifik dalam Langkah-langkah saintifik (PAI) di Madrasah". 
In jurnal Cendekia Vol. 12 No. 1 Juni, pp. 35, 2014

[3] Nurlena Rifa'i, dalam "Seminar Menyongsong Implementasi Kurikulum Pendidikan Agama Islam (PAI ), 2013 , [Online]. Diakses 22 Juni 2018]

[4] Hamruni. Strategi Pembelajaran. Yogyakarta: Insan Madani. Ma'arif, Syamsul, 2012.

[5] Tim Prima Pena, Kamus Besar Bahasa Indonesia, edisi terbaru, Jakarta, Citra Media Press.t.th.

[6] Daryanto. Pendekatan Pembelajaran Saintifik Kurikulum 2013. Yogyakarta: Gava Media, 2014.

[7] Kemendikbud. Pendekatan, Jenis Dan Metode Penelitian Pendidikan. Jakarta: T.P, 2013.
[8] Irwan Sahaja, dalam "ElemenElemen Perubahan Kurikulum 2013, [Online]. Tersedia: http://irwansahaja.blogspot.com/201 6/04/elemen-elemen-perubahankurikulum-2013.html [Diakses 26 Juni 2018]

[9] Ratna Dahar. Teori-teori Belajar dan Pembelajaran. Jakarta: Erlangga, 2006

[10] Lili Hidayati, Kurikulum 2013 dan Arah Baru Pendidikan Agama Islam. Insania, Vol. 19, No. 1, Januari - Juni 2014. [Online]. [Diakses 26 Juni 2018]

[11] Abdul Majid. Belajar dan Langkahlangkah saintifik .Bandung: Remaja Rosdakarya, 2012. 